\title{
A NUMERICAL MODEL FOR DENITRIFICATION OF MUNICIPAL LANDFILL LEACHATE AND PARAMETRIC ANALYSIS ON DENITRIFICATION CONTROLLING FACTORS
}

\author{
kOHJI MICHIOKU ${ }^{1}$, KENJI TANAKA ${ }^{2}$, HIROYA TANAKA ${ }^{2}$, KOSUKE INOUE $^{2}$, \\ TAMIHIRO NAKAMICHI ${ }^{3}$, MASAHIRO YAGI ${ }^{3} \&$ NARIAKI WADA $^{4}$ \\ ${ }^{1}$ Department of Civil and Environmental Engineering, Hosei University, Japan \\ ${ }^{2}$ Kobe University, Japan \\ ${ }^{3}$ Kobe Institute of Health, Kobe City, Japan \\ ${ }^{4}$ Faculty of Environmental Science, University of Shiga Prefecture, Japan
}

\begin{abstract}
In order to develop a new technology for denitrifying leachate by using fatty acid compounds (FAC), a water quality model was developed by considering balances of nitrogen, dissolved oxygen, carbon, phosphorus and denitrification bacteria involved in leachate denitrification. FAC is expected to function not only as a donor of hydrogen and carbon to nourish and activate denitrification bacteria but also as a reducer of nitrified leachate. Prior to the present study, performance of FAC for denitrifying leachate was confirmed in a laboratory experiment under various conditions of leachate loading discharge and nutrients. Time-dependent behaviours of water quality observed in the experiment were successfully reproduced by the model with high accuracy. The model also provides a solution of denitrification performance as a function of hydraulic retention time, HRT. The proposed water quality model is expected to be a useful engineering tool for planning, designing and constructing a cost-saving leachate treatment system.
\end{abstract}

Keywords: landfill leachate, denitrification, water quality model, numerical simulation.

\section{INTRODUCTION}

After rapid economic growth during the 1960s and 1970s in Japan, a huge amount of municipal solid waste had been directly dumped in more than 1,500 landfills nationwide prior to the enactment of the waste management and public cleansing law in 1977 . About $70 \%$ of the landfills are located in inland or mountain areas and there is concern that leachate might cause serious contamination in receiving streams especially after heavy precipitation in the catchment.

The landfill investigated in this study is located in the mountainside of Kobe City, Japan. The organic matters and phosphorus in the leachate are mostly filtered out through travelling underground and the most dominant substance contained in the leachate is ammonia nitrogen. In order to minimize the pollutant load, a treatment plant has been in operation after construction of the landfill since about fifty years ago, where the ammonia-rich leachate is nitrified in a sprinkling filter tower and then converted to nitrogen gas in a denitrification tower. Although ammonia concentration at present is not significant as it used to be, it is still higher than the target level, $60 \mathrm{mg} / \mathrm{l}$. Since the present treatment facility is aging and no longer economically feasible, it needs to be replaced by a new alternative system as soon as possible.

The biological method consisting of nitrification and denitrification processes is one of the most popularly used technologies for leachate treatment [1]. Nitrification is the process in which ammonium or ammonia is oxidized into nitrite by ammonia-oxidizing bacteria or $\mathrm{AOB}$ and the nitrite is further oxidized into nitrate by nitrite-oxidizing bacteria or NOB. Denitrification is the process which reduces nitrates to nitrogen gas with the aid of 
denitrifying bacteria or DB [2]. So far, researches were extensively carried out on leachate treatment for nitrogen removal. Many of them were concentrated on treatment systems by using membrane biological reactors [3]-[5], ion exchange resins technique [6], constructed wetlands [7], etc.. While the nitrification and denitrification processes are usually operated in two separated reactors like the case in Kobe, some integrated plants were devised by combining the two processes such as a sequencing batch reactor (SBR [8]), a rotating biological contactor (RBC [9], [10]), an anaerobic sequencing batch reactor (ASBR) and the pulse sequencing batch reactor (PSBR) proposed by Zhu et al. [11].

Prior to the study on denitrification, the authors have carried out an experiment and water quality modelling on leachate nitrification in which the micro-bubble aeration was adopted to oxidize the leachate [12]. Therefore, attention is paid only on denitrification of leachate in this study. So far, the authors have experimentally examined the denitrification performance of fatty acid compounds (FAC) which nourishes denitrifiers as a hydrogen donor and carbon resource [13]. The FAC used in the experiment was "Amteclean N" produced by PANASONIC [14]. A laboratory experiment was carried out by loading leachate into a test column in which spherical carriers coated with FAC were packed as shown in Fig. 1. In addition to its function as a hydrogen donor and carbon resource, the FAC was found to activate the anaerobic denitrifier by reducing the biofilm on the carriers to become anoxic. In this study, a water quality model was developed in order to numerically reproduce denitrification of leachate. After verification of the model through comparison with the experimental data, the model was applied for evaluating the denitrification performance as a function of hydraulic retention time, HRT.

\section{SUMMARY OF LABORATORY EXPERIMENT}

The test column in Fig. 1 was a vinyl chloride cylinder of one litter in volume capacity. The leachate sample was collected from the sprinkling filter tower and loaded to the test column. Since ammonia contained in the raw leachate was completely aerated in this stage, the dominant component in the sampled leachate was nitrate nitrogen. Because microorganism, phosphorus and degradable carbon were sparse in the leachate, the bottom mud sediment was collected from the leachate impoundment and paved on the floor of the test column with the

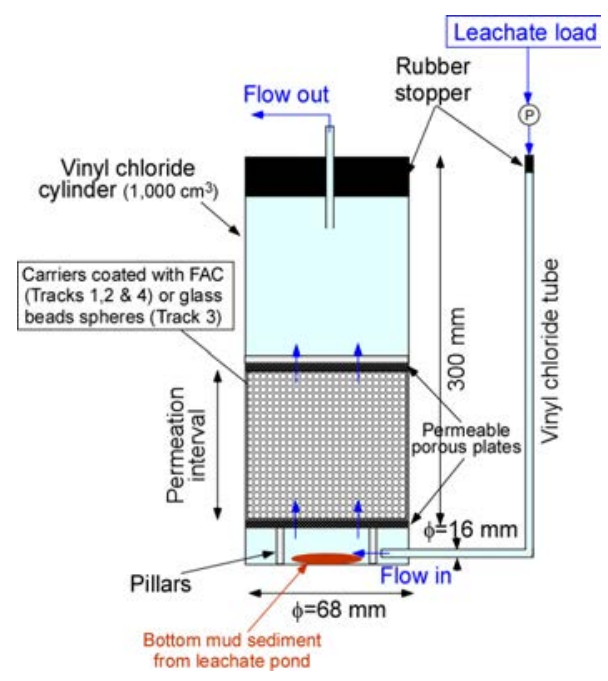

Figure 1: Experimental setup of leachate denitrification. 

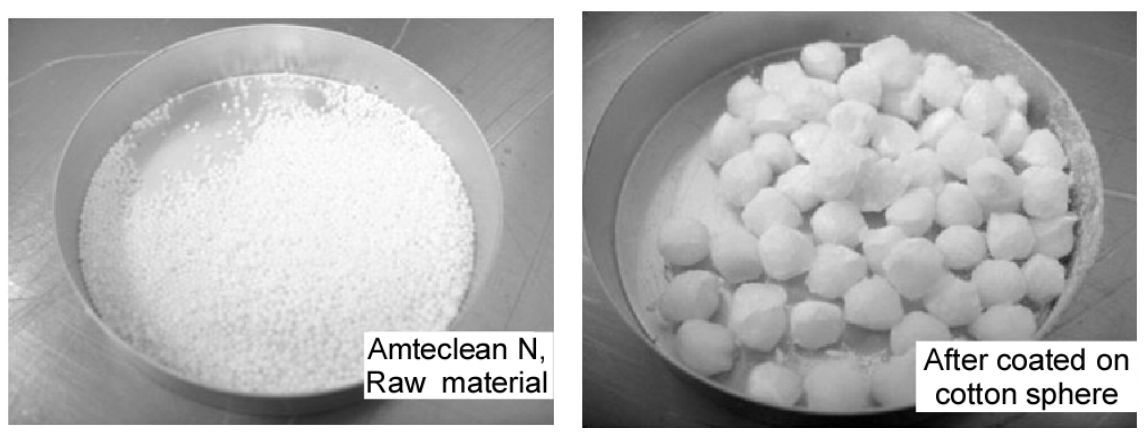

Figure 2: Fatty acid compounds "Amteclean-N" and carriers coated with FAC.

expectation that it would function as a denitrification driver. The microbe-bound carriers were manufactured by impregnating cotton spheres in the thermally melted FAC ("Panasonic, Amteclean-N") as pictured in Fig. 2. The diameter of the carriers was about $6.5 \mathrm{~mm}$.

The experimental conditions are listed in Table 1. Four experimental runs that are termed to be "Tracks" hereafter wee conducted under different conditions of carriers and nutrients. In Tracks 1, 2 and 4, carriers coated with FAC were packed in the column. The amount of the carriers was varied and the total surface area of carriers in Tracks 1,2 and 4 were about $1,000,2,000$ and $4,000 \mathrm{~cm}^{2}$, respectively. Track 3 was a reference case packed with the same amount of carriers as Track 4 but the carriers were glass beads that were spheres of $5.0 \mathrm{~mm}$ in diameter with no FAC-coating. Therefore, the carriers in Track 3 released no hydrogen and no degradable carbon to the ambient leachate. Comparison between Tracks 3 and 4 may provide information on how the FAC functions as hydrogen and carbon resources for promoting denitrification. Contribution of phosphorus to denitrification can be confirmed by comparing the results between Tracks 1, 2 and 4 .

After packing the carriers and filling the leachate in the test column, the leachate sample was acclimated for 24 hours. After then, the experiment in each track was simultaneously started by continuously feeding the leachate to the test column at a constant discharge $Q$. Air temperature in the laboratory was kept around $22^{\circ} \mathrm{C}$. After confirming that denitrification reached a steady state, $Q$ was then increased stepwisely from 0.5 to $1.0,2.0,4.0,8.0$ $\mathrm{ml} / \mathrm{min}$ to vary the hydraulic retention time, HRT. By doing so, dependency of the denitrification rate on HRT could be examined. In the middle stage in Tracks 3 and 4, methanol was added in order to find out how much denitrification was inspired and promoted by the methanol. The experimental dataset was analysed and findings from the experiment were applied for developing the water quality model.

\section{WATER QUALITY MODEL}

The water quality balance in the reactor is assumed to be like the schematic in Fig. 3. By considering both oxidation and reduction of substances, the water quality model can be constructed as a comprehensive model which can describe biochemical processes occurring not only in anaerobic but also in aerobic conditions. In our previous study on leachate nitrification, the water quality modelling for nitrification was completed and the model parameters were already identified [12]. Therefore, discussion here is primarily concentrated on modelling of denitrification. For example, as shown in Fig. 1, both natural aeration at the water surface and the micro-bubble aeration in Fig. 3 are absent in the present model. 
Table 1: Experimental conditions and time histories in each track.

\begin{tabular}{|c||c|c|c|c|}
\hline \multicolumn{1}{|c||}{} & Track 1 & Track 2 & Track 3 & Track 4 \\
\hline \hline Carriers & Carriers with FAC coating & $\begin{array}{c}\text { Glass beads } \\
\text { spheres }\end{array}$ & $\begin{array}{c}\text { Carriers with } \\
\text { FAC coating }\end{array}$ \\
\hline $\begin{array}{c}\text { Total surface area of } \\
\text { packed carriers } A\left(\mathrm{~cm}^{2}\right)\end{array}$ & 1,000 & 2,000 & 4,000 & 4,000 \\
\hline Phosphorus & \multicolumn{3}{|c|}{ Added } & None \\
\hline
\end{tabular}

\begin{tabular}{|c|c|c|c|c|c|}
\hline Date & $\begin{array}{c}\text { Elapsed } \\
\text { days }\end{array}$ & Track 1 & Track 2 & Track 3 & Track 4 \\
\hline October 1 & 0 & (0.5ml/min & \multirow[t]{2}{*}{ "0.5ml/min } & \multirow[t]{3}{*}{ (20.5ml/min } & \multirow[t]{6}{*}{ "0.5ml/min } \\
\hline 8 & 7 & $1.0 \mathrm{ml} / \mathrm{min}$ & & & \\
\hline 25 & 24 & \multirow[t]{5}{*}{$\begin{array}{c}A=4,000 \mathrm{~m}^{2} \\
\rightarrow 1,000 \mathrm{~m}^{2}\end{array}$} & \multirow[t]{2}{*}{$1.0 \mathrm{ml} / \mathrm{min}$} & & \\
\hline 26 & 26 & & & $\begin{array}{c}\text { Start to add } \\
\text { methanol }\end{array}$ & \\
\hline November 8 & 38 & & \multirow[t]{4}{*}{$2.0 \mathrm{ml} / \mathrm{min}$} & & \\
\hline 11 & 41 & & & $\begin{array}{l}\text { Finish to } \\
\text { add } \\
\text { methanol }\end{array}$ & \\
\hline 15 & 45 & & & & \multirow[t]{3}{*}{$\begin{array}{c}\text { Start to add } \\
\text { methanol }\end{array}$} \\
\hline 25 & 55 & $2.0 \mathrm{ml} / \mathrm{min}$ & & Finish & \\
\hline $\begin{array}{r}\text { December } \\
14 \\
\end{array}$ & 74 & \multirow[t]{2}{*}{$4.0 \mathrm{ml} / \mathrm{min}$} & \multirow[t]{2}{*}{$4.0 \mathrm{ml} / \mathrm{min}$} & & \\
\hline 21 & 81 & & & & \multirow[t]{2}{*}{$\begin{array}{c}\text { Finish to add } \\
\text { methanol }\end{array}$} \\
\hline 28 & 88 & $0.5 \mathrm{ml} / \mathrm{min}$ & $0.5 \mathrm{ml} / \mathrm{min}$ & & \\
\hline January 11 & 102 & $8.0 \mathrm{ml} / \mathrm{min}$ & $8.0 \mathrm{ml} / \mathrm{min}$ & & Finish \\
\hline 20 & 108 & Finish & Finish & & W \\
\hline
\end{tabular}

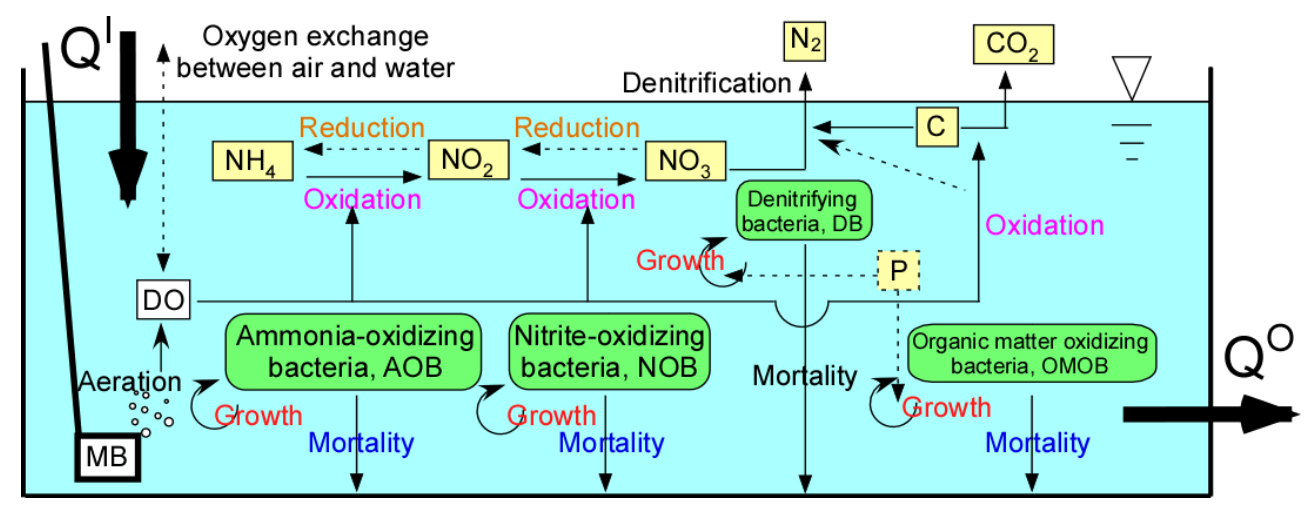

Figure 3: Schematic of water quality model. 
Now, let $C_{\mathrm{j}}$ to be concentration of the j-th component of water quality, the mass balance in the reactor is generally described as

$$
V \frac{d C_{\mathrm{j}}}{d t}=Q\left(C_{\mathrm{j}}^{\mathrm{I}}-C_{\mathrm{j}}\right)+V \cdot S\left(C_{\mathrm{j}}\right)
$$

where $V$ : volume capacity of the reactor, $C_{\mathrm{j}}^{\mathrm{I}}$ : inflow concentration of the j-th component, $Q$ : loading discharge and $S\left(C_{\mathrm{j}}\right)$ : production and dissipation rate in the biochemical reaction, respectively.

$S\left(C_{\mathrm{j}}\right)$ in eqn (1) should be formulated with respect to (i) nitrogen, (ii) carbon, (iii) phosphorus, (iv) dissolved oxygen, and (v) microorganism. The model formulation for each component is summarized as follows.

\subsection{Nitrogen}

Balances of ammonia-, nitrite- and nitrate nitrogen are considered. Their reactions are controlled by concentrations of related substances such as nitrogen components themselves, microorganisms, i.e. AOB, NOB, DB, dissolved oxygen and degradable carbon. Anammox reaction is not considered for analytical simplicity.

Here, the reaction rate only of the nitrate nitrogen $S\left(\mathrm{NO}_{3}\right)$ is demonstrated as an example. The nitrate nitrogen $\mathrm{NO}_{3}-\mathrm{N}$ is produced from the nitrite nitrogen by the nitrite-oxidizing bacteria NOB and consumed by denitrification with the aid of the denitrifying bacteria DB, respectively. $\mathrm{DB}$ is generally classified into anaerobic $\mathrm{B}_{\mathrm{ND}}$ and aerobic bacteria $\mathrm{B}_{\mathrm{NDO}}$. In the present model, only the parameters regarding $B_{N D}$ are identified, assuming $B_{N D}$ to be the only dominant species responsible for denitrification. Namely, the term for $\mathrm{B}_{\mathrm{NDO}}$ is added in the equation for future extension of the model but they are tentatively disregarded in the analysis. Both $\mathrm{B}_{\mathrm{ND}}$ and $\mathrm{B}_{\mathrm{NDO}}$ are heterotrophic bacteria that needs carbon and phosphorus as resources of hydrogen and nutrients. Therefore, the Michaelis-Menten kinetics relating to carbon and phosphorus is applied as control functions of denitrification. As a result, the production and dissipation rate of $\mathrm{NO}_{3}-\mathrm{N}$, i.e. $S\left(\mathrm{NO}_{3}\right)$, is written as

$$
\begin{aligned}
& S\left(N O_{3}\right)=\frac{R_{\mathrm{N} 2} \cdot f_{\mathrm{N} 2}(T) \cdot \frac{D O}{D_{\mathrm{N} 2}+D O} \cdot \frac{B_{\mathrm{NO}_{2}}}{B_{\mathrm{N} 2}+B_{\mathrm{NO}_{2}}} \cdot \frac{N O_{2}}{C_{\mathrm{N} 2}+N O_{2}}}{\text { nitrite oxidation }} \\
& \frac{-R_{\mathrm{ND}} \cdot f_{\mathrm{ND}}(T) \cdot \frac{D_{\mathrm{ND}}}{D_{\mathrm{ND}}+D O} \cdot \frac{B_{\mathrm{ND}}}{B_{\mathrm{NDD}}+B_{\mathrm{ND}}} \cdot \frac{N O_{3}}{C_{\mathrm{ND}}+N O_{3}}}{\text { denitrification by anaerobic denitrifier }} \times \\
& \frac{\left(\phi_{11} \cdot \frac{C_{\text {ori }}}{C_{\mathrm{Co}}+C_{\text {ori }}}+\phi_{12} \cdot \frac{C_{\text {amte }}}{C_{\mathrm{Ca}}+C_{\text {amte }}}+\phi_{13} \cdot \frac{C_{\text {meth }}}{C_{\mathrm{Cm}}+C_{\text {meth }}}\right)}{\text { denitrification by anaerobic denitrifier }} \\
& -R_{\mathrm{NDO}} \cdot f_{\mathrm{NDO}}(T) \cdot \frac{D O}{D_{\mathrm{NDO}}+D O} \cdot \frac{B_{\mathrm{NDO}}}{B_{\mathrm{NDDO}}+B_{\mathrm{NDO}}} \cdot \frac{N O_{3}}{C_{\mathrm{NDO}}+N O_{3}} \times \\
& \frac{\left(\phi_{21} \cdot \frac{C_{\text {ori }}}{C_{\text {OCo }}+C_{\text {ori }}}+\phi_{22} \cdot \frac{C_{\text {amte }}}{C_{\text {OCa }}+C_{\text {amte }}}+\phi_{23} \cdot \frac{C_{\text {meth }}}{C_{\text {OCm }}+C_{\text {meth }}}\right)}{\text { denitrification by aerobic denitrifier }},
\end{aligned}
$$

where [ $\left.\mathrm{DO}, \mathrm{NO}_{2}, \mathrm{NO}_{3}\right]$ : concentration of $\mathrm{DO}, \mathrm{NO}_{2}-\mathrm{N}$ and $\mathrm{NO}_{3}-\mathrm{N}$, respectively, $\left[R_{\mathrm{N} 2}, R_{\mathrm{ND}}\right.$, $R_{\mathrm{NDO}}$ ]: rates of nitrite oxidation, anaerobic and aerobic denitrification at reference condition, respectively, $\left[f_{\mathrm{N} 2}(T), f_{\mathrm{ND}}(T), f_{\mathrm{NDO}}(T)\right]$ : control functions depending of water temperature $T$ for 
each reaction, [ $B_{\mathrm{NO} 2}, B_{\mathrm{ND}}, B_{\mathrm{NDO}}$ ]: concentrations of NOB, $\mathrm{B}_{\mathrm{ND}}$ and $\mathrm{B}_{\mathrm{NDO}}$, respectively, [ $D_{\mathrm{N} 2}$, $\left.B_{\mathrm{N} 2}, C_{\mathrm{N} 2}, B_{\mathrm{NDD}}, C_{\mathrm{ND}}, D_{\mathrm{NDO}}, B_{\mathrm{NDDO}}, C_{\mathrm{NDO}}\right]$ : half saturation constants in nitrification and denitrification, $D_{\mathrm{ND}}$ : switching constants for $D O$ in anaerobic denitrification, [ $C_{\text {ori }}, C_{\text {amte }}$, $\left.C_{\text {meth }}\right]$ : concentrations of three carbon components which are (i) dissolved carbon originally contained in the leachate, (ii) "Amteclean-N" as FAC and (iii) methanol, respectively, $\left[C_{\mathrm{Co}}\right.$, $\left.C_{\mathrm{Ca}}, C_{\mathrm{Cm}}, C_{\mathrm{OCo}}, C_{\mathrm{OCa}}, C_{\mathrm{OCm}}\right]$ : half saturation constants relating to each carbon resource in denitrification, and $\left[\varphi_{11}, \varphi_{12}, \varphi_{13}, \varphi_{21}, \varphi_{22}, \varphi_{23}\right]$ : weighting constants for each carbon resource, which satisfy $\varphi_{11}+\varphi_{12}+\varphi_{13}=1$ and $\varphi_{21}+\varphi_{22}+\varphi_{23}=1$.

Equations for $\mathrm{NH}_{4}-\mathrm{N}$ and $\mathrm{NO}_{2}-\mathrm{N}$ are also formulated in the same manner as in eqn (2).

\subsection{Carbon}

Three components of carbon are considered as discussed in 3.1. They are consumed for denitrification and aerobic degradation, while supplied from leachate, FAC or methanol depending on the condition in each track. According to our experimental result, it is considered that the dominant component of carbon in the leachate is low-degradable organic substance and scarcely spent for denitrification.

\subsection{Phosphorus}

Equation for $\mathrm{PO}_{4}-\mathrm{P}$ is formulated, by considering that phosphate phosphorus $\mathrm{PO}_{4}-\mathrm{P}$ is consumed to nourish the denitrifying bacteria and the carbon oxidizing bacteria, COB.

\subsection{Dissolved oxygen}

Balance equation for dissolved oxygen DO is formulated by integrating loss due to oxidation of nitrogen and degradation of organic matters and gain from atmosphere and the MB aerators if they exist.

\subsection{Microorganism}

Considering biochemical reaction involved in oxidation and reduction of nitrogen and carbon, growth and mortality rates are formulated with respect to $A O B, N O B, D B\left(B_{N D}, B_{N D O}\right)$ and COB.

\section{WATER QUALITY ANALYSIS ON DENITRIFICATION OF LEACHATE}

The solution for time-dependent concentration of each component is obtained by simultaneously integrating a set of the differential equations discussed above. The model parameters were iteratively identified so that the analytical solutions gain the best fit to the experimental data. The solutions for the time-dependent concentration of ( $\mathrm{T}-\mathrm{N}, \mathrm{NO}_{3}-\mathrm{N}, \mathrm{NO}_{2}-$ $\mathrm{N}), \mathrm{DO}, \mathrm{PO}_{4}-\mathrm{P}$ and TOC are plotted in Figs 4-7, respectively. In the figures, symbols are the experimental data and lines the numerical solutions provided by the model, respectively.

In Tracks 1 and 2, the FAC-coated carriers were packed and $\mathrm{PO}_{4}-\mathrm{P}$ was fed for nourishing the denitrifiers. Therefore, time histories of DO in Fig. 5 clearly demonstrates that DO was substantially spent by organic matters released from FAC, which brought the system to be anoxic from the beginning of the experiment. In such an anaerobic condition, denitrification was significantly promoted, which is recognized in the decreasing tendency of TN observed in Fig. 4(a). 


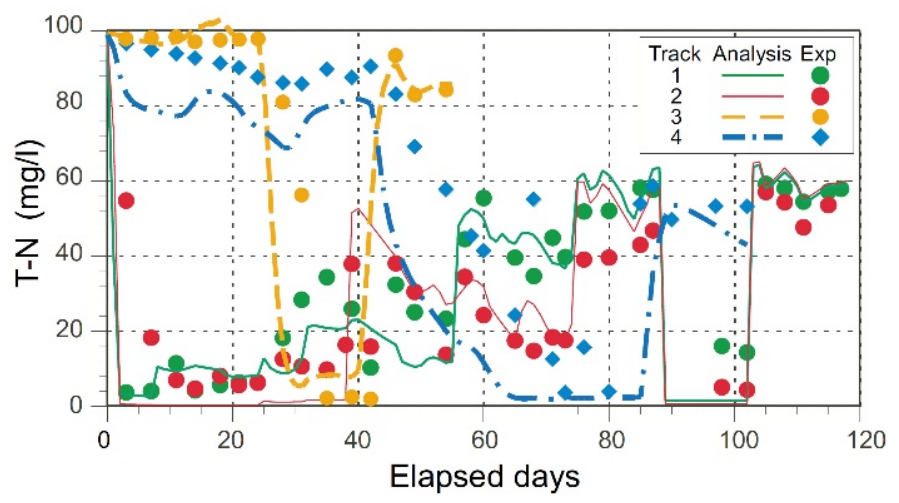

(a)

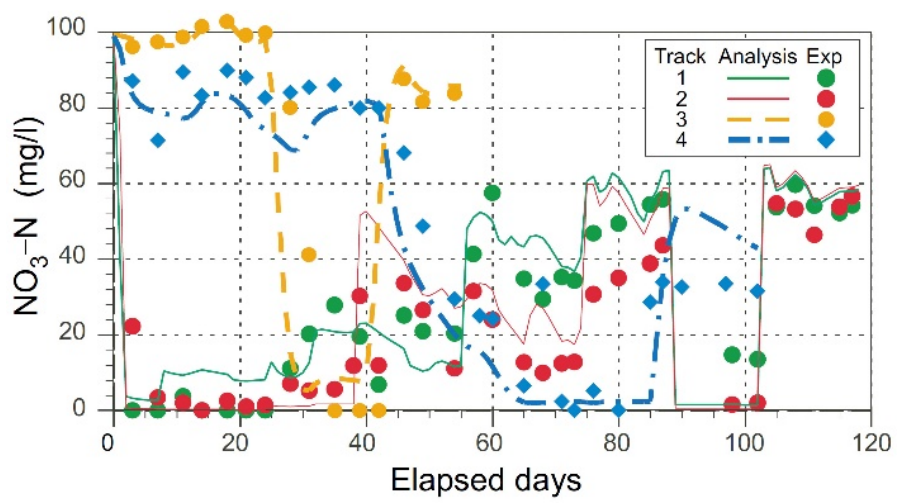

(b)

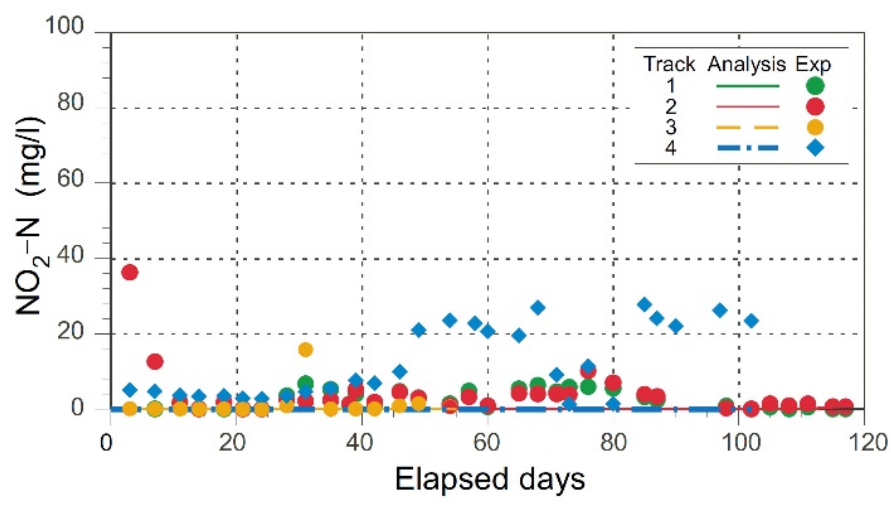

(c)

Figure 4: Time histories of nitrogen components. (a) Total nitrogen T-N; (b) Nitrate nitrogen $\mathrm{NO}_{3}-\mathrm{N}$; (c) Nitrite nitrogen $\mathrm{NO}_{2}-\mathrm{N}$. 


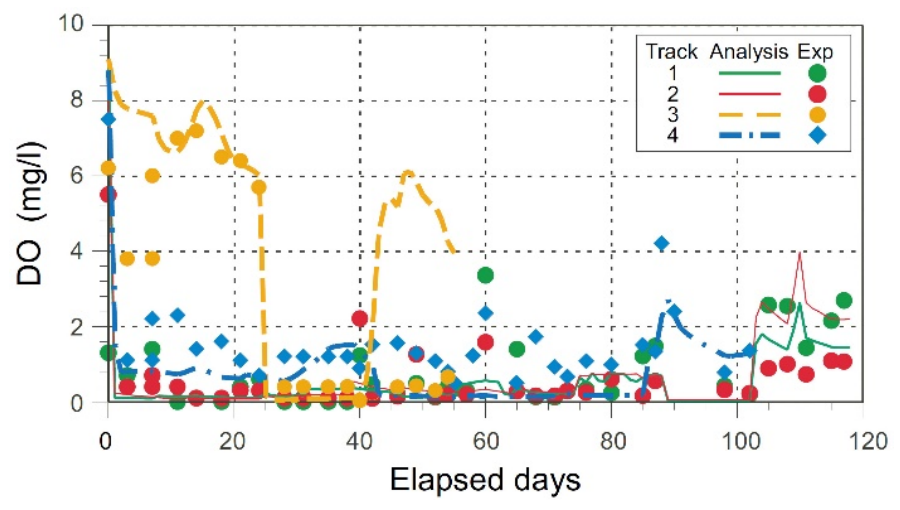

Figure 5: Time histories of dissolved oxygen DO.

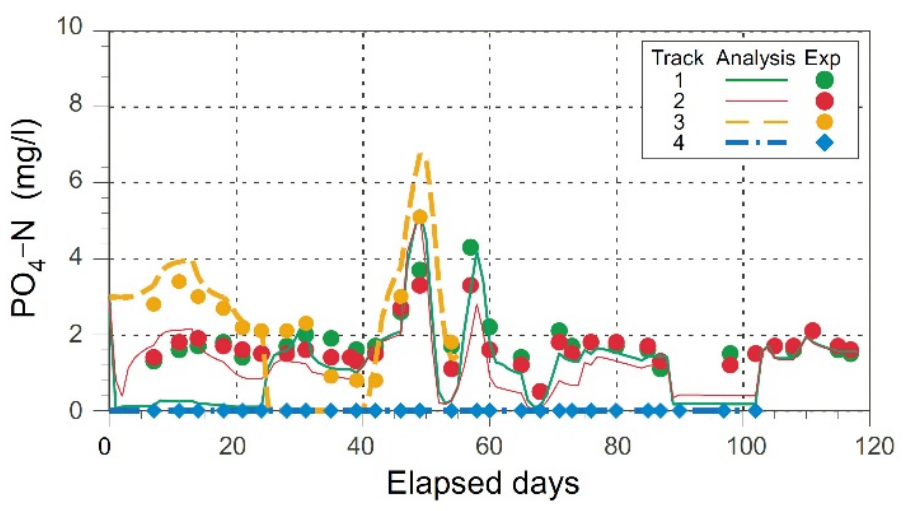

Figure 6: Time histories of phosphate phosphorus, $\mathrm{PO}_{4}-\mathrm{P}$.

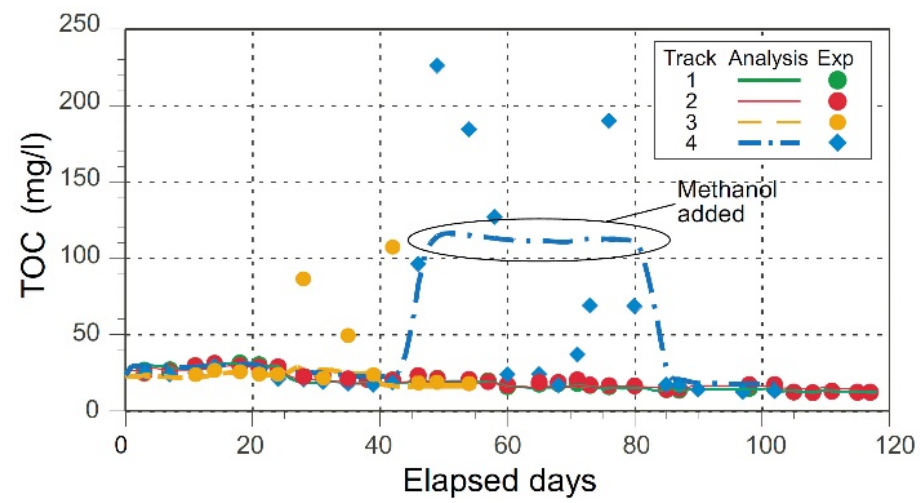

Figure 7: Time histories of total carbon TOC. 
After then, denitrification was decelerated by increasing the leachate load stepwisely as from $Q=0.5,1.0,2.0,4.0$ to $8.0 \mathrm{ml} / \mathrm{min}$ (see Table 1). For a larger discharge, more T-N and $\mathrm{NO}_{3}-\mathrm{N}$ remained unused as seen in Fig 4(a) and 4(b). A good agreement is observed between the model and experiment in every track. The model shows an excellent reproducibility of denitrification processes such as being accelerated by the FAC-coated carriers, and on the contrary, decelerated by the leachate load.

In Track 3 shown in Fig. 4(a), only glass bead spheres were packed in the column and T$\mathrm{N}$ concentration was kept unchanged in the absence of carbon resource until the 26th day when the methanol feeding started. But, right after the 26th day, the system was immediately converted to an anoxic state and then T-N instantaneously began to decrease. The model shows a good agreement with the experiment in such denitrification behaviours in Track 3.

As observed until the 45th day in Fig. 4(a), denitrification in Track 4 was much slower than those in Tracks 1 and 2, despite the fact that twice or four times more FAC-coated carriers were packed than in Tracks 1 and 2. It is considered that such sluggish denitrification in Track 4 at this stage was caused by a shortage of phosphoric acid. Nevertheless, soon after starting the methanol feeding on the 45th day as shown in Fig. 7, T-N immediately decreased. This result suggests that that a carbon resource like methanol with higher degradability could efficiently accelerate denitrification even when the phosphoric acid is missing. On the contrary, in Track 3 in which little degradable carbon exists, the leachate was scarcely denitrified even if the phosphoric acid was sufficiently supplied.

Summarizing the results, highly degradable carbon is a necessary resource for denitrification, while the phosphorus has a function to accelerate the process but does not play a role as a limiting factor. The water quality model shows an excellent performance in reproducing how denitrification was promoted by adding methanol and phosphoric acid.

\section{INFLUENCE OF HYDRAULIC RETENTION TIME, HRT, ON DENITRIFICATION}

Tracks 1 and 2 were carried out in order to examine how the leachate loading discharge $Q$ [1/day] affects denitrification performance. Since both FAC and phosphorus were sufficiently supplied in the two tracks, denitrification was not controlled by FAC nor by phosphorus. Therefore, the only limiting factor is considered to be $Q$ in this case. $Q$ was stepwisely varied as shown in Table 1 and the hydraulic retention time, HRT, defined by $V / Q$ [day], accordingly varies in the same manner, where $V[l]$ is the volume capacity of the test column. As discussed before, denitrification approached a steady state at the end of each experimental step. Therefore, assuming the denitrification rate to be constant in this moment, performance of denitrification $\alpha$ can be evaluated by

$$
\alpha=\frac{[\mathrm{T}-\mathrm{N}]^{\mathrm{I}}-[\mathrm{T}-\mathrm{N}]^{\mathrm{O}}}{[\mathrm{T}-\mathrm{N}]^{\mathrm{I}}},
$$

where $[\mathrm{T}-\mathrm{N}]^{\mathrm{I}}$ and $[\mathrm{T}-\mathrm{N}]^{\mathrm{O}}$ are inflow and outflow concentrations of $\mathrm{T}-\mathrm{N}$ at the end of each experimental step. $\alpha$ obtained in this manner is plotted against the corresponding HRT in Fig. 8. In the figure, the data points denote the experimental results and the solid curves show the analytical solutions given by the model. The analytical values in the figure are obtained from the data after reaching a biochemically equilibrium state under a given condition. Since attention here is primarily paid on the influence of HRT on denitrification, it is approximated in the analysis that the system is completely anoxic and has sufficient concentration of denitrifying bacteria. Namely, put the control functions both of DO and the denitrifying bacteria to be 1.0 in the water quality model. Increasing tendency of the denitrification performance $\alpha$ with HRT is properly demonstrated by the model. It is also confirmed in the figure that a higher performance of denitrification is achieved in Track 2 than in Track 1, 


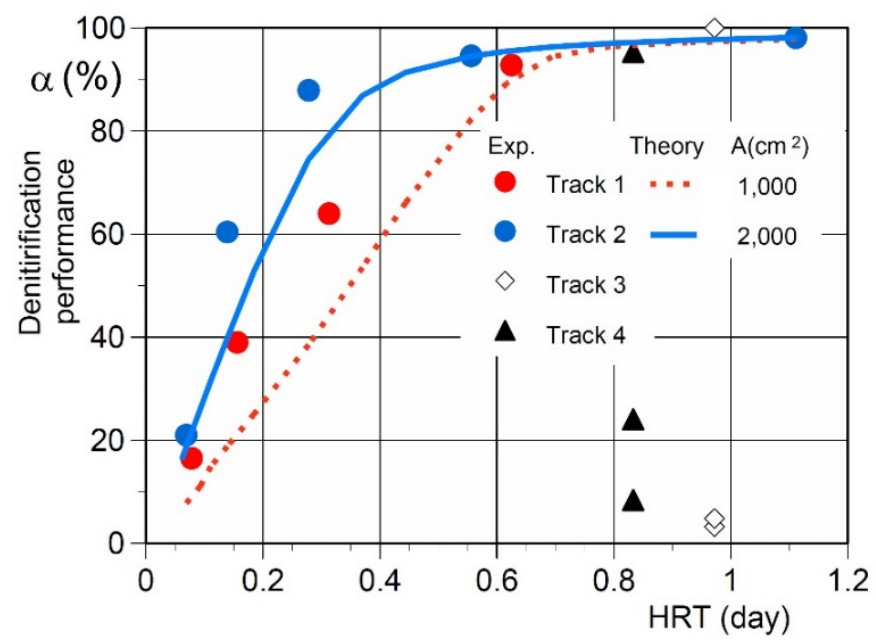

Figure 8: Dependency of denitrification rate on hydraulic retention time, HRT.

because the total surface area of FAC-coated carriers in the former is twice as large as in the latter. The analytical solutions for functional dependencies of denitrification on HRT and FAC are in excellent agreement with the experimental data.

\section{CONCLUDING REMARKS}

A water quality model was developed in order to investigate the performance of a new material of fatty acid compound, FAC, for denitrifying leachate. Based on findings from the laboratory experiment, biochemical production and dissipation of nitrogen, carbon, phosphorus, dissolved oxygen and microorganism are formulated in the model. The analytical solutions show a good agreement with the experimental data for time-dependent behaviours of water quality. In addition, a functional relationship between the denitrification performance and the hydraulic retention time, HRT, was analysed, which provides useful information for planning and designing an economically feasible treatment system. According to the present analysis and the laboratory experiment, FAC is found to be a very promising material for efficiently removing nitrogen from heavily contaminated leachate.

The next step of the study should be to confirm performance of the water quality model in reproducing the nitrogen removal process in a prototype scale. The authors proposed a treatment system in which nitrification and denitrification are simultaneously in progress in a single reactor with the aid of the micro-bubble aeration and the fatty acid compound. This could be a concept of labour-saving and economically feasible leachate treatment system. A laboratory experiment proved that the proposed system is scientifically feasible [15]. Therefore, after verification of the present model through comparison with the laboratory data, it should be applied to a prototype scale in order to figure out a necessary discharge of MB aerator and a required amount of FAC. In this manner, the water quality model could be an engineering tool in future for establishing a sustainable waste management.

\section{ACKNOWLEDGEMENT}

The present study was financially supported by the Grant-in-Aid for Scientific Research (C) (Project No. 17K06588, Leader: Kohji Michioku). 


\section{REFERENCES}

[1] Welander, U., Henrysson, T. \& Welander, T., Biological nitrogen removal from municipal landfill leachate in a pilot scale suspended carrier biofilm process. Water Research, 32(5), pp. 564-1570, 1998. DOI: 10.1016/s0043-1354(97)00351-5.

[2] Borzacconi, L., Ottonello, G., Castell, E., Pelaez, H., Gazzola, A. \& Vi, M., Denitrification in a carbon and nitrogen removal system for leachate treatment: Performance of a upflow sludge blanket (USB) reactor. Water Science and Technology, 40(8), pp. 145-152, 1999. DOI: 10.1016/s0273-1223(99)00620-4.

[3] Schwarzenbeck, N., Leonhard, K. \& Wilderer, P.A., Treatment of landfill leachate high tech or low tech? A case study. Water Science and Technology, 48(11-12), pp. 277-284, 2004. DOI: 10.2166/wst.2004.0860.

[4] Vasel, J.L., Jupsin H. \& Annachhatre, A.P., Nitrogen removal during leachate treatment: Comparison of simple and sophisticated systems. Water Science and Technology, 50(6), pp. 45-52, 2004. DOI: 10.2166/wst.2004.0358.

[5] Hasar, H., Ipek, U. \& Kinaci, C., Joint treatment of landfill leachate with municipal wastewater by submerged membrane bioreactor. Water Science and Technology, 60(12), pp. 3121-3127, 2009. DOI: 10.2166/wst.2009.748.

[6] Bashir, M.J.K., Aziz, H.A., Yusoff, M.S., Huqe, A.A. \& Mohajeri, S., Effects of ion exchange resins in different mobile ion forms on semi-aerobic landfill leachate treatment. Water Science and Technology, 61(3), pp. 641-649, 2010.

DOI: $10.2166 /$ wst.2010.867.

[7] Sawaittayothin, V. \& Polprasert, C., Nitrogen mass balance and microbial analysis of constructed wetlands treating municipal landfill leachate. Bioresource Technology, 98(3), pp. 565-570, 2007. DOI: 10.1016/j.biortech.2006.02.002.

[8] Diamadopoulos, E., Samaras, P., Dabou, X. \& Sakellaropoulos, G.P., Combined treatment of landfill leachate and domestic sewage in a sequencing batch reactor. Water Science and Technology, 36(2-3), pp 61-68, 1997.

DOI: 10.1016/s0273-1223(97)00370-3.

[9] Siegrist, H., Reithaar, S., Koch, G. \& Lais, P., Nitrogen loss in a nitrifying rotating contactor treating ammonium-rich wastewater without organic carbon. Water Science and Technology, 38(8-9), pp. 241-248, 1998. DOI: 10.1016/s0273-1223(98)00698-2.

[10] Cema, G., Wiszniowski, J., Żabczyński, S., Zabłocka-Godlewska, E., Raszka, A. \& Surmacz-Górska, J., Biological nitrogen removal from landfill leachate by deammonification assisted by heterotrophic denitrification in a rotating biological contactor (RBC). Water Science and Technology, 55(8-9), pp. 35-42, 2007.

DOI: 10.2166/wst.2007.239.

[11] Zhu, R., Wang, S., Li, J., Wang, K., Miao, L., Ma, B. \& Peng Y., Biological nitrogen removal from landfill leachate using anaerobic-aerobic process: Denitrification via organics in raw leachate and intracellular storage polymers of microorganisms. Bioresource Technology, 128, pp. 401-408, 2012.

DOI: 10.1016/j.biortech.2012.10.063.

[12] Michioku, K., Nakamichi, T., Yagi, M. \& Wada, N., A water quality model for aeration of leachate from garbage dumped landfill. Proceedings of the 6th International Symposium Environmental Hydraulics, 2, pp. 1053-1058, 2010.

[13] Michioku, K., Tanaka, K., Yagi, M., Nakamichi, T. \& Wada, N., An experimental study on denitrification of leachate continuously loaded from a municipal waste landfill. Groundwater Modeling and Management under Uncertainty, eds Hadi \& Copty, Taylor \& Francis Group, pp. 297-305, 2012. 
338 Waste Management and the Environment IX

[14] Murasawa, K., Osamura, K., Morisaki, H., Sano, A., Terada, T. \& Tainaka, Y., Direct denitrification of a canal using fatty acid compounds as a hydrogen donors. Journal of Japan Society on Water Environment, 25(12), pp. 737-742, 2002. DOI: 10.2965/jswe.25.737 (in Japanese).

[15] Michioku, K. et al., An experiment on simultaneous operation of nitrification and denitrification of municipal landfill leachate in a single reaction tank. Proceedings of Water Pollution, 228, pp. 131-143, 2018. 